\title{
Stripes between the Sacred and the Profane
}

\author{
Ljiljana Stošić
}

Institute for Balkan Studies, Serbian Academy of Sciences and Arts (SASA), Belgrade, Serbia

Copyright $\bigcirc 2017$ by authors, all rights reserved. Authors agree that this article remains permanently open access under the terms of the Creative Commons Attribution License 4.0 International License

\begin{abstract}
During the Renaissance, in the West, stripes gradually ceased to be used as a sign of the evil, sinful and negative. It was probably under the influence of the Crusades and vast epidemics of plague that striped patterns covering entire fabrics or only their borders to be perceived as an expression of constant movement and life, bearing previously unimaginable connotations of such concepts as ceremony, exoticism and freedom. What remains and persists to this day are the visual accent and the perceptual priority of striped patterns. The relationship between stripes and proscriptions and punishment, especially temporary exclusion from social life, is not coincidental. As kind of barrier, passage or protection from evil powers and diabolical creatures, stripes were early visualized as a warning, they became a kind of protection cages, and they have remained this, in the true sense of the word, to this day. Stripes always bring system and order into world of chaos, indicating the belonging to a particular zone, level or sphere and offering an opportunity for a hierarchical classification.
\end{abstract}

Keywords Stripes, Sacred and Profane, Byzantine Painting, Renaissance, Enlightenment, System and Order

\section{Introduction}

In most Western European languages, the verb strip has a double meaning; along with its basic meaning, this word implies deletion, removal and elimination, in terms of expulsion or exclusion from a list. Latin words such as stria and strigilis are derived from stringo, which has multiple meanings, including attach, tie, lift, take off, strip, cut off, rip off, deprive and denude. The association of stripes with prohibition and punishment, and especially the long-term exclusion from society, has never been coincidental. Acting as a kind of barrier, passage, gate, filter or defence against evil powers and diabolical creatures who never leave people alone, stripes were rather early visualized as a warning and they became sort of protective cages, which they truly remain even today.

\section{Historical Review}

\section{The Middle Ages}

In Western medieval culture, striped suits or striped details on clothes were meant to indicate an infidel or a heretic (a Jew, a Muslim, an Oriental man), an Old Testament or a New Testament sinner, a dishonourable man or an apostate (Cain, Delilah, Saul, Salome, the Prodigious Son, Judas, devil), village fool, street crook, adulteress, juggler, musician, witch doctor, executioner, freak or a man suffering from an incurable or infectious disease. In other words, stripes were used to mark persons that should be avoided and kept at a safe distance [1,2]. This type of representations first appeared in secular miniatures of the $12^{\text {th }}$ and $13^{\text {th }}$ centuries and, subsequently, in Gothic frescoes. Rigidly relying on symbolic forms and structures, Western medieval culture sought to represent as different anything that conflicted with the accepted social norms and religious beliefs, marking such elements with stars, circles or polka dots, squares or lozenges, as well as narrow or wide stripes and gaudy colours.

Instead of striped clothes, Romanesque and Byzantine art favoured striped backgrounds consisting of two to three wide or several narrow stripes intended to discreetly enclose a biblical event in a protected and consecrated, sacred space. Rows of archpriests, priests or deacons, whose strip-like epitrachelia and oraria symbolize the grace of the Holy Spirit and angel wings, make a distinct group of images. They are meant to remind us of the cross carried by Christ on His shoulders on the way to Golgotha, as well as of the will of God that should be carried out quickly and dexterously always and on every opportunity, as befits the servants of the Lord. The fragments of frescoes from 1190-1199, discovered in the church of St John, founded by Prince Miroslav, at Crnča, a village by the Bijelo Polje - Berane road (Montenegro), feature striped fabrics that "emphasize the body, while having their own visual value". These are namely the cloths that appear in the Nativity of Christ, the scene which either shows the newborn Saviour already swathed or midwives preparing to wrap Him in cloths after the first bath [3]. Only a few 
years later, in the frescoes of the Serbian monastery of Studenica (1208-1209), the heads of the holy hymnographers of Arab origin would be adorned with exotic striped headbands. Judging by these early examples, as well as by some other instances (Hosios David, Dečani), Oriental striped fabrics had found their place in the art of the Christian East as a distinguishing mark of holy characters considerably earlier than in Western European painting, without being assigned negative secular meanings.

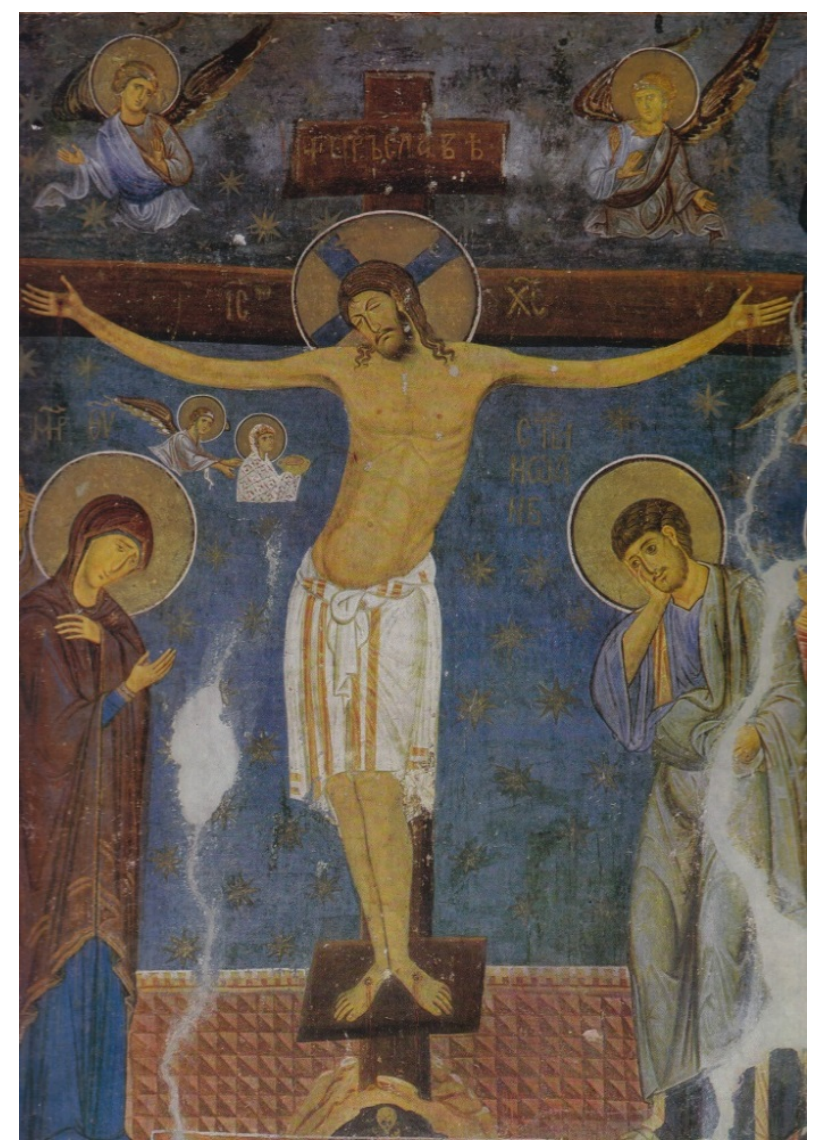

Figure 1. Crucifixion, fresco detail (1208-1209), Serbia, church of the Holy Virgin at the monastery of Studenica

In Serbian medieval painting, gold stripes appear mainly as borders on white cloths in the Crucifixion [Fig. 1], Dormition of the Holy Virgin [Fig. 2] and the Holy Mandylion. These are namely the bedding on the Holy Virgin's death bed, the perizoma or the loin cloth wrapped around Christ's hips tied in a knot, and the cloth (Mandylion) imprinted with the acheiropoieton (not-made-by-human-hands) image of Christ. Starting from the Ottoman period, particularly since the $16^{\text {th }}$ century, these sacred fabrics were increasingly often adorned with Oriental stripes. This also applies to the Holy Mandylion, which was believed to have the power to protect against visible and invisible enemies but also from sudden death. Stripes were sometimes featured in Mandylion's counterpart - the Holy Keramion (Holy Tile), i.e. an acheiropoieton image of Christ imprinted on a tile (e.g. the late $17^{\text {th }}$-century Keramion from the Skete of the Holy Trinity at Spasova Voda near the Hilandar monastery on Mount Athos). Both acheiropoieta images of Christ are the evidence of the Saviour's temporary stay on earth and his belonging to the transcendental and eternal. Nevertheless, these images also bear unambiguous associations of their authentic origin from Asia Minor and the Orient and serve as evidence of an early Christianization of the local population in these areas (cf. the legend of King Abgar of Edessa).

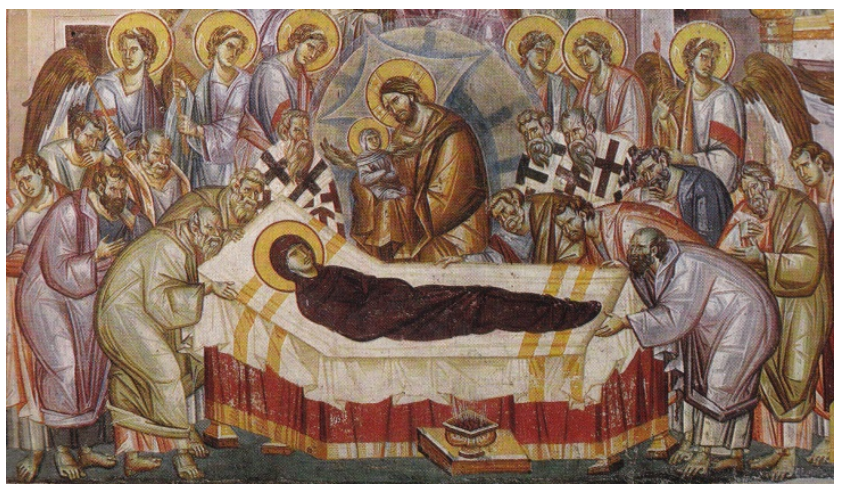

Figure 2. Dormition of the Holy Virgin, fresco detail (1294-1295), Macedonia, church of the Virgin Peribleptos in Ohrid

\section{Renaissance}

During the Renaissance, in the West, stripes gradually ceased to be used only as a sign of the evil, sinful and negative. It was probably under the influence of the Crusades and vast epidemics of plague, that striped patterns covering entire fabrics or only their borders began to be perceived as an expression of constant movement, life and fickle fortune [4], bearing previously unimaginable connotations of such concepts as ceremony, exoticism and freedom (e. g. Martin le Franc, Allegory of Destiny, manuscript, mid- $15^{\text {th }}$ century). What remains and persists to this day are the visual accent and the perceptual supremacy of striped patterns. The artist who went the farthest in rendering the subtlety of the striped fabric in which Christ's dead body had been wrapped was Sandro Botticelli during his religious phase stirred by his friendship with Savonarola. In his Pietà (1495-1500) held by the Poldi-Pezzoli Museum in Milan, the tragic drama of the Gospel event is expressed through the play of draperies wrapping all of the depicted participants in superhuman pain. In this painting, striped fabrics in direct contact with Christ's calmly reclining naked body stand out and capture sight with their tactile gentleness, subtlety and beauty [5]. 


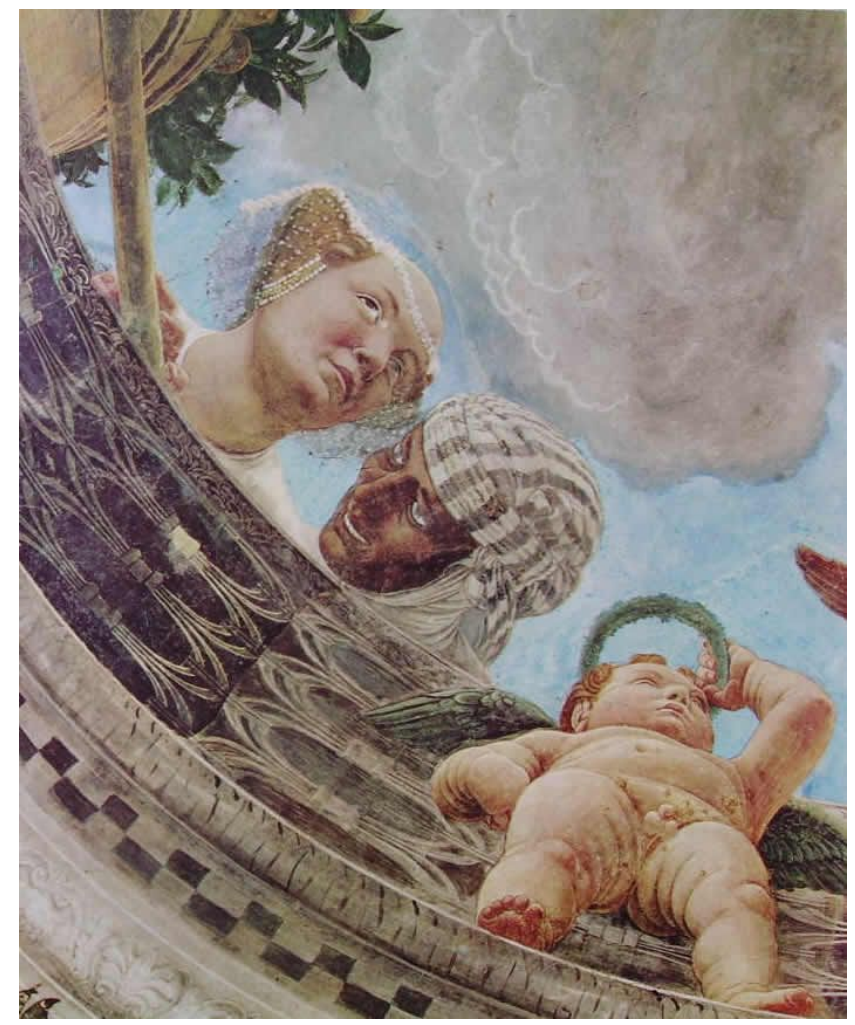

Figure 3. A. Mantegna, Oculus, fresco detail (1465-1474), Italy, Mantua, Palazzo Ducale, Camera degli Sposi

During this period, painters often used striped patterns to emphasize, make an association, classify and juxtapose. The dynamics and rhythm of stripes anticipate an event and indicate the transition from one state to another. This does not apply only to religious but also to secular scenes in which the world of the white man meets that of the black man. Western European painters believed that stripes had been adopted from the East and, accordingly, they more often used striped details [Fig. 3] on the clothes of dark-faced characters (Andrea Mantegna, Camera degli Sposi, 1465-1474) or white men in their immediate vicinity (Paolo Veronese, The Feast in the House of Levi, 1573), in order to make a contrast. In his most famous self-portrait (1498), held by the Prado (Madrid), the young Dürer is shown in eye-catching, almost troubadour-style black-and-white striped suit with a cap, highlighting his artistic self-awareness and male beauty [6]. As opposed to horizontal stripes, which appeared on the dress of peasants and servants - from maids and cup-bearers to messengers and falconers - as a leftover of their negative reception in Western European medieval culture, vertical stripes were considered to be more sophisticated. Starting with Balthazar, the only dark-skinned among the Magi who came from the East to visit the newborn Christ, vertical stripes [Fig. 4] adorned the dress of aristocrats and rulers (Jean Clouet, Portrait of Francois I, 1525-1530), who held themselves in high esteem and sought to perpetuate the image of themselves as men in full vigour [7].

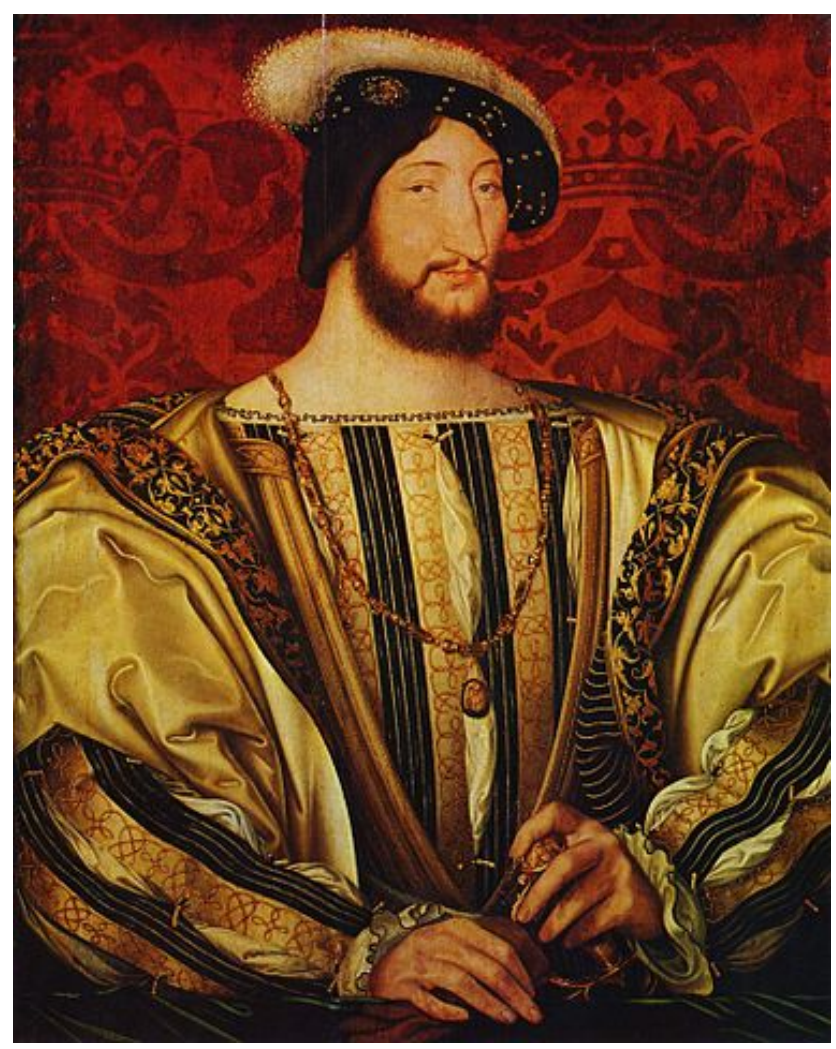

Figure 4. J. Cloue, Portrait of Francois I, oil on canvas (1525-1530), France, Paris, Louvre

\section{Baroque and Rococo}

During the $17^{\text {th }}$ century, striped men's garments, such as sleeves, sleeveless vests and trousers (Michelangelo Caravaggio, The Calling of Saint Matthew, 1599-1600), were fashionable in Spain. Nevertheless, women's striped cloaks (Francisco de Zurbarán, St Dorothy, 1640-1650) were equally remarkable. In the 1710 s, Jean-Antoine Watteau, as a true representative of the French age galant, eagerly depicted his male and female characters in suits, long gowns and capes adorned with vertical stripes in pastel colours [8], highlighting the delicacy and rustling of velvety silk and velvet. In his frescoes painted in the mid- $18^{\text {th }}$ century, Giovanni Battista Tiepolo garbed swarthy pages and oriental-looking ambassadors in striped turbans and vests (The Banquet of Cleopatra, Palazzo Labia, Venice). At the same time, stripes appeared in the form of vertical grooves on pilasters and columns in the most sumptuous and the most beautiful palaces of the time, such as Schönbrunn in Vienna and Sanssouci in Potsdam. Since the second half of the $18^{\text {th }}$ century, stripes shifted from representative attire to the lining, calling for social and moral change, in the sense of "being and remaining strong". It was in that context that around 1740, Hristofor Žefarović portrayed the Bishop of Buda, Vasilije Dimitrijević [9] known for his arbitrariness, impulsiveness, and the love of money (the portrait is presently held by the Bishop's Palace in Szentendre). 


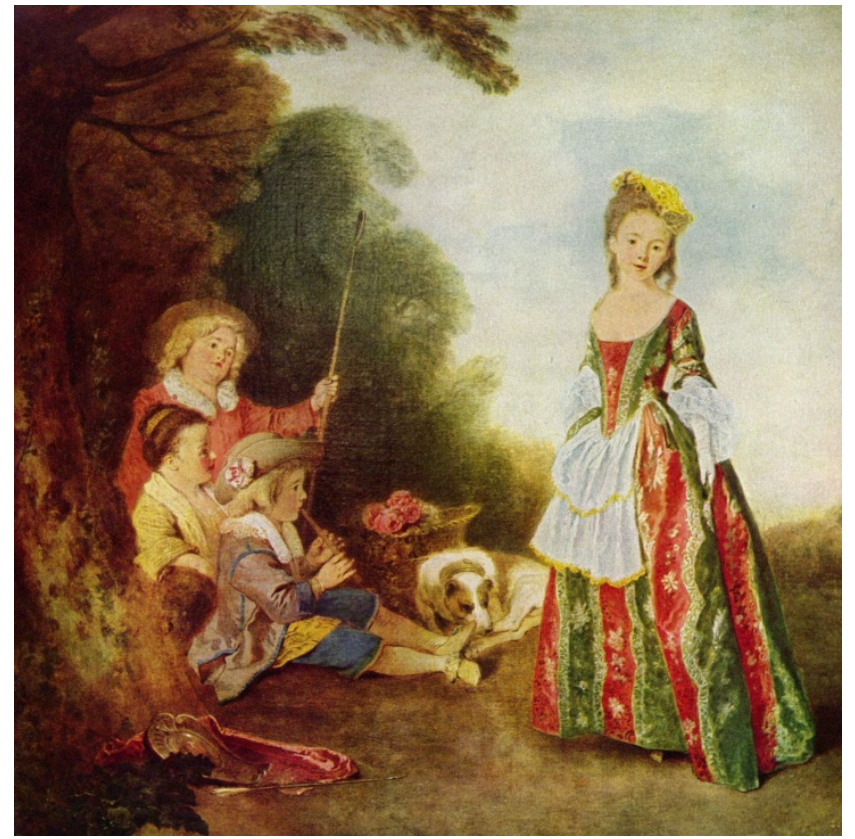

Figure 5. A. Watteau, The Dance, oil on canvas (1716-1718), Germany, Berlin, Staatliche Museen

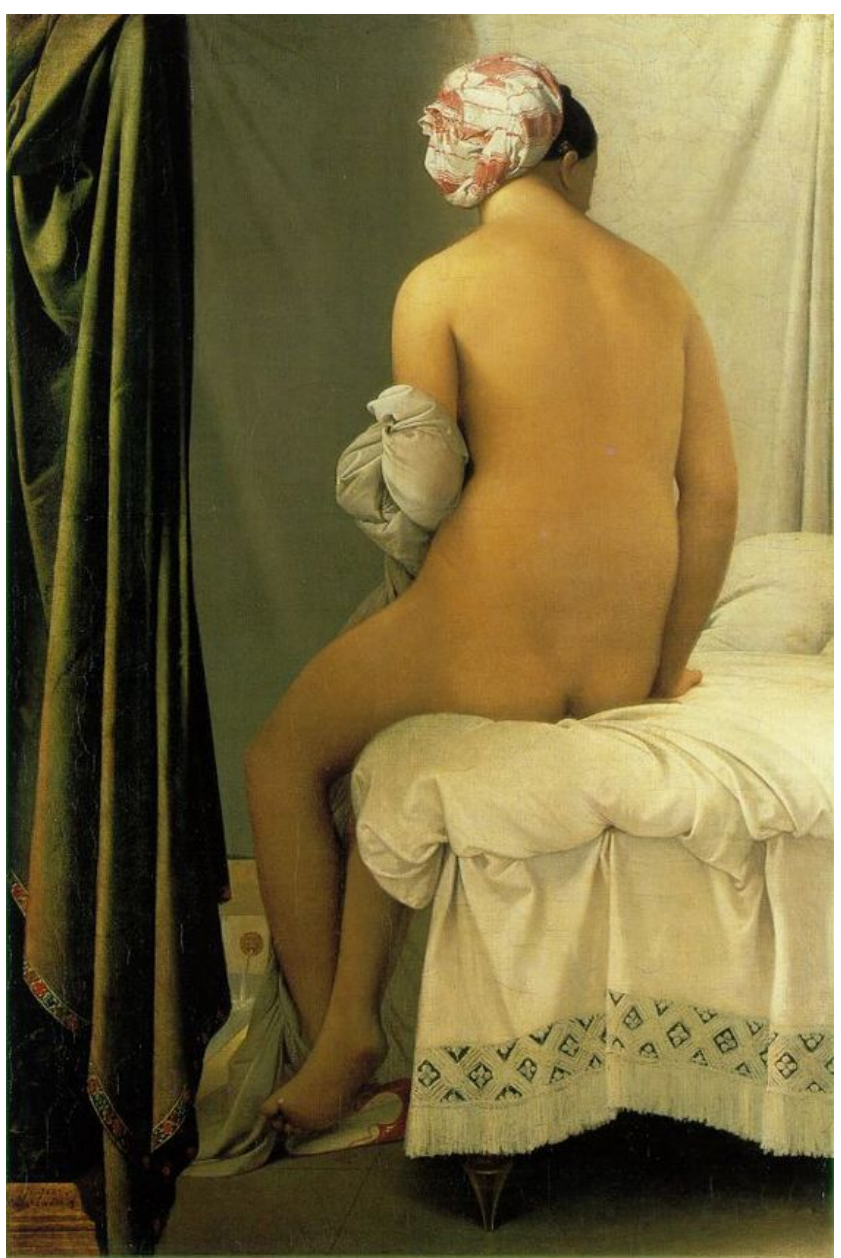

Figure 6. J.-A.-D. Ingres, Valpincon Bather, oil on canvas (1808), France, Paris, Louvre
The obsession of the official French fashion with Turkish clothing details in the $18^{\text {th }}$ century also found its expression in children's clothes worn when going out to the garden and playing with their mates, as evidenced by $\mathrm{A}$. Watteau in his painting Dance (1716-1718), where the girl in a striped dress is shown as a princess from a fairy tale [Fig. 5]. In the adult world of the early $19^{\text {th }}$ century, the striped costume still bore associations of the Oriental life (J.-A.-D. Ingres, Valpincon Bather, 1808), seeking to make the depicted persons look like a sultan or sultana at the court, or an odalisque in a Turkish bath, relaxing with while listening to the sounds of pleasant music in foggy vapors of warm, fragrant and refreshing baths [Fig. 6] - or seeking to take distance from them through rejection.

\section{Enlightenment and Modern World}

In the Age of Enlightenment, especially after the American and French, stripes unstoppably pervaded everyday life, becoming a phenomenon that pervaded all social strata and leaving the vicious circle of pejorative connotations that had persisted since the Middle Ages. Apart from ceremonial dress, they spread to underwear, socks, bedding, including mattresses and pyjamas, as well as towels and kitchen napkins [10]. In the late $19^{\text {th }}$ century, they reached ocean ships and prisons as distinct and recognizable uniforms. After the French Revolution, the red-white-blue three-coloured flag became a symbol of independence and freedom. Only a few decades later, stripes would also pervade hospital rooms, swimming pools and beaches (beach chairs, umbrellas, towels, swimwear, sandals, bags), and they would become common as a favourite motif in children's clothing (from bibs to breeches) and dress of bank clerks (narrow stripes), as well as notorious gangsters (wide stripes on the suits of Al Capone and his followers). Apart from idlers, stripes were readily adopted among youth, athletes (athlete suits of local and national teams), as well as all those who loved and led a healthy life (the sport brand Adidas) and enjoyed casual entertainments (lollipops, candy canes, peppermint, chewing gums).

\section{Results}

The Messmer-Žefarović Stemmatographia (1741) features a number of flags which are entirely or partially striped (Austria, Hungary, Greece, Pannonia, Ragusa Dubrovnik). The coats of arms of many Venetian, Ragusan and Serbian aristocratic families were also striped. Nowadays, the national flags of the USA, Greece and Cuba abound in stripes. The flag of the United States has seven red and six white stripes to mark a total of thirteen British colonies that once won independence from of the United Kingdom, becoming the first United States 
of America. The Greek flag consists of five blue and four white stripes, a total of nine, symbolizing the nine muses and nine arts and civilizations of the world. The distinguishing feature of the flag of the LGBT population are the eight colors of the rainbow, each of which has a special meaning: pink - sexuality, red - life, orange healing power, yellow - sunlight, green - nature, turquoise - art and magic, blue - seriousness and harmony, and purple - spirituality.

No matter whether they worked in the areas to the north of the Sava and Danube rives or in the southern regions of the Balkan Peninsula, the last Late Byzantine and the earliest Baroque painters in the late $17^{\text {th }}$ and the early $18^{\text {th }}$ century enriched the inherited tradition with elements of contemporary stylistic features. They not only garbed Biblical characters - such as the Holy Virgin, Jesus Christ, Adam and Eve, the Holy Trinity depicted as angles or St John Damascene - in decorative striped fabrics that were in direct contact with the body but they also used them to dress and define them, highlighting their sacred symbolism [11]. While gravitating towards Venetian or Oriental cultural spheres, Serbian artists pained striped patterns to illustrate the fabulous fortune of the Persians (Teodor Kračun, Esther before Ahasuerus, 1774) or depict the radiant otherworldly mandorlas that created a strong energy field (Petar Rafailović, Descent into Hades, around 1760).

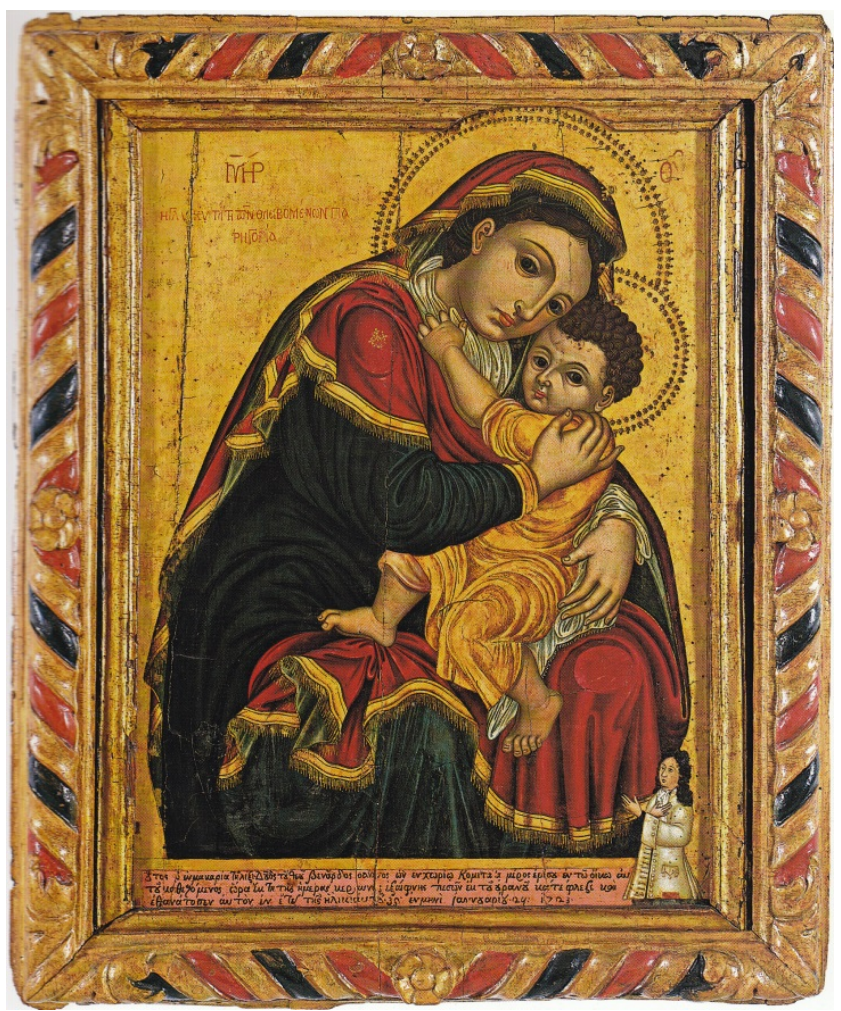

Figure 7. Anonymous, Holy Virgin Glykophilousa, icon (1723), Greece, Athens, Byzantium and Christian Museum

The icon of the Holy Virgin Glykophilousa painted by an unknown Greek artist is an extraordinary work of art. It is an indirect copy of Raphael's tondo Madonna della Sedia (ca. 1516) and is presently held by the Byzantine and Christian Museum in Athens [12]. This painting, rendered in three primary colours - red, blue and golden yellow, also has a striking three-coloured striped frame [Fig. 7]. The lower right corner features a small half-length figure of the deceased Venardos Anninos, who was suddenly killed by lightning at his home in the age of thirty-five. The icon was commissioned by the Anninos family immediately after the funeral of the young man shown in white robes praying to the Virgin of Consolation. The three-coloured striped frame marks the boundary between the sacred and the real space. As a reflection of the desire for resurrection and eternal life through the Virgin Mary, who sacrificed herself and who helps in the salvation of those who suffered martyrdom without guilt, in the Greek painting, Venardos Anninos replaces the little St John the Baptist, who in Rafael's [13] painting prays for himself and for his mate, the Saviour crucified in the age of thirty-three. In the work of the anonymous Greek artist, painted two centuries later, the stripes that in Raphael's painting adorn the Virgin's robe and headdress are shifted to the icon's frame, thereby highlighting its funerary function.

As a renowned portraitist, Miloš Golubović painted the wedding half-length portraits of Milan and Ljubica Grol (1934); they are shown facing one another, as if placed in an open diptych or a medallion. In doing this, he assumed the same approach as in a series of portraits of his family, where he obsessively repeated the motifs of a woman and children, while interweaving personal life and allegorical subjects related to the portrayed person. Ljubica Grol is shown meditating with her hands folded; she rests her head upon them above a bunch of letters, placed next to her husband's books and family photos; she is shown in her warm and soft peignoir with blue stripes on a white background. Although depicted realistically, with freshly applied lipstick, her image is not an image of a living woman. Half-open eyes that are about to close show that at the time when she was painted the lady had been in a deep and eternal sleep for five years. The striped peignoir of Mrs Grol was obviously an expression of her husband's desire to have her back in his home, at least as an illusion. For this reason, the portrait was probably painted after an earlier photo that was dear to him.

Edvard Munch's Self-Portrait: Between the Clock and the Bed was painted just a few years before the artist's death in 1944 [Fig. 8]. This masterpiece is also one of his last paintings. Painted in Munch's solitary house near Oslo, where he had spent the last twenty-eight years of his life, this self-portrait is an image of a Lord's servant who is readily waiting for his last moment. The dial of the clock is not shown because it is not known when it will finally stop. Munk is relaxed and garbed in festive dress; he is sitting in his immaculately clean home, where 
everything is in place, including his earlier paintings, hanging on the wall. The ascetic and rather hospital-like bed is neatly made and covered with a striped blanket. It seems as if the painter wished to say and show that he would die, when his time came, and would readily step into eternity similarly to the Holy Virgin on her deathbed in Byzantine art.

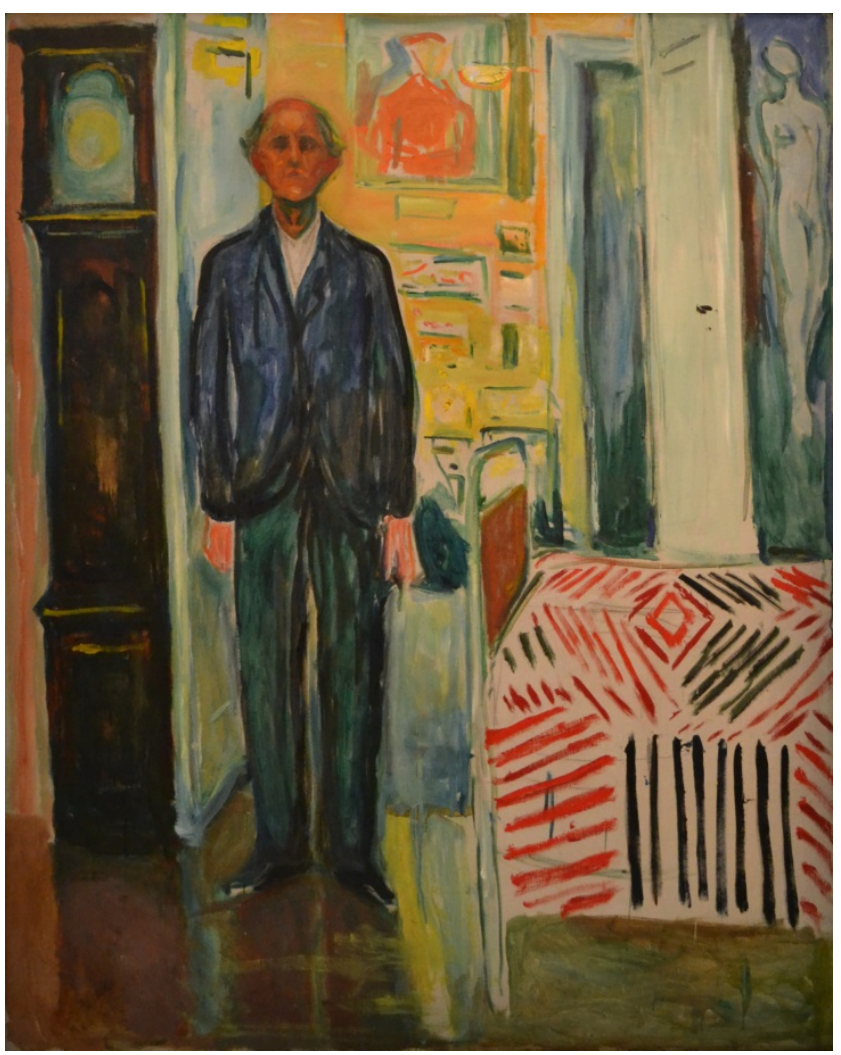

Figure 8. E. Munch, Self-Portrait between the Clock and the Bed, oil on canvas (1942), Norway, Oslo, Edvard Munch Museum

\section{Conclusions}

Gestalt psychologists agree that the most common types of ties, along with polka-dotted ones, are those featuring stripes. According to them, they indicate tidiness, diligence and reliability of the wearer. This must be known to public figures from political life, as soon as they wear and change them so often. Ties less commonly feature horizontal or vertical stripes - stripes in ties are usually diagonal. Unlike the Americans who wear ties with diagonal stripes running from right to left, Europeans mostly wear ties with stripes in the opposite direction. Bow ties may also be striped and this type is particularly chic. The stylist Ašok Murti does not recommend combining a striped suit and tie with a striped shirt. The most famous Belgrade-based fashion designer of ties, Neven Vrgoč, who has been specializing in the design for more than thirty years and has gained world renown, claims that ties give strength and power and reveal a desire to be noticed. This is a fashion accessory that being worn on the most delicate and the most exposed part of the body - attracts, reveals, anticipates, shows the inner side of the personality, but also protects what is most sacred and precious - the soul. The sleeveless cocktail dress Homage to Mondrian, launched in 1965 as a great fashion hit by Yves Saint Laurent, was perceived as "the art that walks": the black stripes on it delimited fields and the basic colors - red, yellow and blue - were used as the means for liberating the spirit to embrace infinite possibilities [14].

Striped dresses and other parts of women's clothing come back into fashion from time to time. During the 2016 spring/summer season, sailor stripes were the latest fashion craze. Fashion designers recommend that they be freely combined as vivid imagination may dictate. As a single striped detail is enough to refresh the entire outfit, stripes reduce the need for additional decorative accessories. Stripes are suited to all occasions; they are eye-catching and they emphasize feminine attributes. Due to their potential to create an optical illusion, they are also used to emphasize individual parts of the body. They can also conceal body flaws. It is an old and well-known sartorial rule that vertical stripes elongate the figure, while horizontal stripes make it look fatter than it really is.

Designers recommend the use of striped details in the interior design of apartments and houses [Fig. 9], as it takes a single striped detail to change the usual appearance of a room. For example, in order to make a bedroom look different, it only takes to cover a single wall with a striped wallpaper or to put a striped blanket on a bed. In a dining room, such details may be combined with floral, polka-dot and tartan designs. Striped patterns are particularly recommended for carpets, rugs, curtains, chairs, sofas, beds, decorative pillows and lampshades. Striped patterns are perfect for every home, as they are considered to be permanently fashionable because of their remarkable visual appearance.

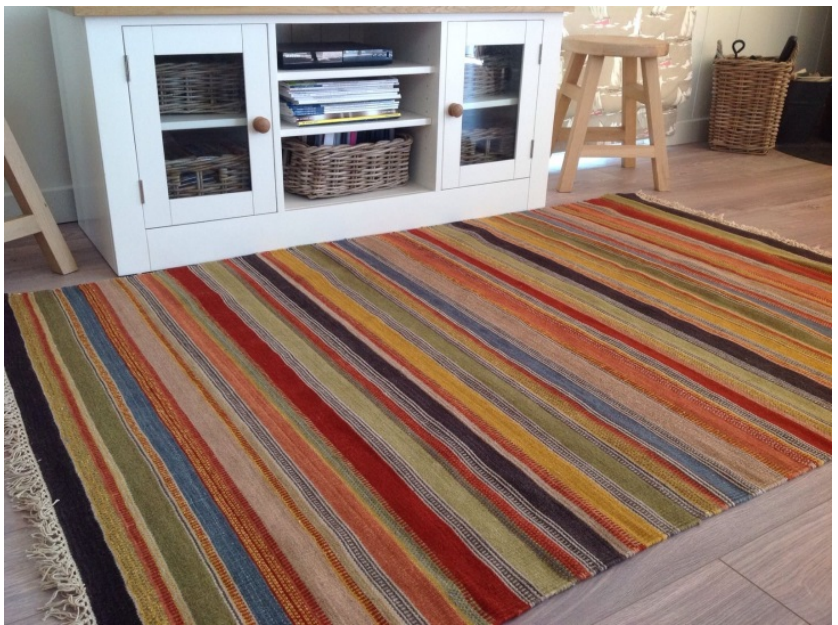

Figure 9. Striped interior 
The logos of many great international car manufacturers feature stripes as a sign of speed, streamlined design and reliability (Buick, Volkswagen, Cadillac, Mini Morris, Porsche, Rover, Seat, Citroen, Suzuki, Fiat). The visual identity of the well-known sports equipment manufacturer Adidas also rests on stripes. Speed races on the athletic stadiums and swimming pools are performed in separate striped lanes. When in the late 1960s the multi-coloured striped Signal toothpaste was launched, it was a sign that others should follow its example, as the Signal toothpaste was sold and consumed more due to its attractive design. From that moment on, teeth brushing became for many a real pleasure, rather than a boring and hated duty. It was another confirmation of the extraordinary qualities of stripes, which set in action everything they touched by leaving an impression of continuous movement.

More recently, stripes have been used to indicate potential danger, as well as a special area the use of which can alternately be prohibited and permitted - i.e. the zebra crossings. The guide stripes for the blind also consist of multiple parallel lines to be followed; however, they are not mandatory but only recommended. Warning traffic signs with diagonal red and white stripes are placed before a road narrowing due to maintenance works, an intersection with a railroad crossing and before toll booths, to inform drivers that they should reduce their speed and stop. Those who do not follow these signs may lose their lives or pay penalties. Nowadays, land transport is unimaginable without stripes and multiple lanes in one or two directions. Until recently, the remote transmission of power was carried out via a system of stripe-like high-voltage wires supported by poles. While the use of stripes among humans is associated with the fastest movement in space, in the animal world, they ensure to the zebras and tigers either good camouflage or easy and unmistakable visibility, depending on whether animals are moving through bushes or in the open field.

Stripes may also be used to protect an area. In case wooden, plastic or Plexiglas blinds are not available, one pulls striped blinds up or down, especially in rooms reserved for rest and sleep. Apart from protecting against the lights of the big city, they act as a visual protection against external noise, cold, rain, snow, heat and sun, as well as all sorts of attacks, including night robberies. Safety barriers and fences that surround houses and divide public and private spaces are constructed using vertical, horizontal or diagonal stripe-like elements.

Barcode is a fairly recent way of marking all legally manufactured products by thirty black and white lines of different widths and lengths [Fig. 10]. The code is read by special laser sensors whenever a product is to be identified when passing from one delimited area to another. The identification code contains information about the country of origin, the manufacturer and the product type, as well as a control number, which includes the price and expiration date. In order to speed up the process, in future, barcode readers will be able to identify all items from a consumer's basket at once. Barcode readers have so far proved very successful in reading codes even at an angle or when a label is partially damaged. By reading a barcode, an item is automatically removed from stock and another, identical item is ordered.

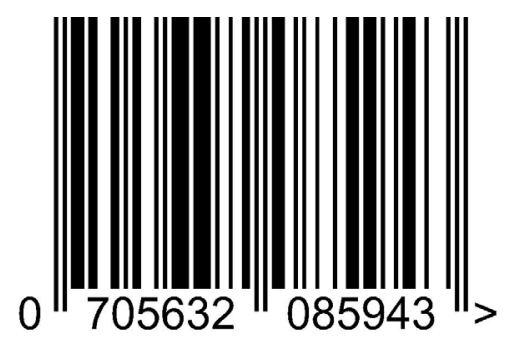

Figure 10. Barcode

\section{Appendix}

At this point, the story of the specially protected and forbidden striped area will temporarily end. All handwritten or printed lines of text in a book, tables and columns, since the earliest woodcut books to today's daily newspapers, official gazettes and encyclopaedias, are unique striped entities, which, as copyrighted property, according to copyright law, are not to be reused in an unauthorized manner, copied or published without legal consequences. The rows of shelves in public and private libraries, upon which books are most commonly lined vertically but also horizontally and diagonally, are made in the form of stripes. The same pattern is repeated in rows of drawers for storing various items. In a world of chaos, stripes always bring system and order, classifying everything and everyone in a particular zone, level or sphere; the classification may also imply a hierarchy. Stripes are there to underline and emphasize, while it is humans' task to take their side by choosing between good and evil. It seems that the sacred and the profane - the two worlds so suggestively marked by stripes throughout history - are no longer so firmly separated, but they rather touch and permeate one another in all possible ways. Anyone who tries to approach those remains puzzled whether the virtual and real worlds are merely two parallel worlds similar to stripes that touch each other, making an inseparable part of a higher sense of existence.

\section{REFERENCES}

[1] M. Pastoureau. The Devil's Cloth: a History of Stripes, Washington Square Press, New York, 1991.

[2] N. Garden, R. Olorenšo, Ž. Garden, O. Klajn. Larousse mali rečnik simbola, Laguna, Beograd, 2011. 
[3] B. Popović. Fresco Fragments from the Church of St John at Crnča, Djurdjevi stupovi and the Eparchy of Budimlja, Collection of Papers, Bishopric of Budimlja and Nikšić, Faculty of Philosophy, Berane - Belgrade, 361-368, 2011.

[4] T. Voronova, A. Sterligov. Illuminated Manuscripts, Grange Books, London, 2007.

[5] M. L. Rizzati. Botticelli, Arnoldo Mondadori Editore, Milano, 1974.

[6] L. Cummings. A Face to the World on Self-Portraits, Harper Collins Publishers, London, 2009.

[7] U. Eko. Istorija lepote, Plato, Belgrade, 2004.

[8] V. Charles, K. H. Carl. Rococo, Parkstone Press International, New York, 2010.

[9] O. Mikić, Bishopric Portraits at the Budim Library Courth in Sentendre, Recueil de Sentandrea, Vol. 1, No. 1, 42, 1987.

[10] Willet, C., Cunnington. P. The History of Underclothes, Dover Publications, London, 1951.

[11] Lj. Stošić. The Iconostasis of Maksim Tujković at Nikoljac near Bijelo Polje, Collection of Papers, Bishopric of Budimlja and Nikšić, Faculty of Philosophy, Berane Belgrade, 637-652, 2011.

[12] M. Acheimastou Potamianou. Icons of the Byzantine Museum of Athens, Archeological Receipts Fund Directions of Publications, Athens, 1998.

[13] C. Pescio. Palazzo Pitti, Bonechi, Firenze, 1981.

[14] R. Milosavljević. Design: Art for Carry, Politika (Belgrade), 2017, Novembar 12, 28. 